\title{
Limbah Kayu dan Kertas Bekas Untuk Pulp Kertas
}

\author{
Sarbin* \\ Pengolahan Hasil Hutan, Politani \\ Negeri Samarinda, 75131 \\ sarbinrahmanbgr@gmail.com \\ *Corresponding author \\ Noorhamsyah \\ Pengelolaan Hutan, Politani Negeri \\ Samarinda, 75131 \\ noorhamsyah2018@yahoo.com
}

\author{
Iskandar \\ Rekayasa Kayu, Politani Negeri \\ Samarinda, 75131 \\ iskandar.smd.799@gmail.com
}

\author{
Arini Rajab \\ Pengelolaan Lingkungan, Politani \\ Negeri Samarinda, 75131 \\ arinirajab@gmail.com
}

\author{
Abdul Rasyid Zarta \\ Rekayasa Kayu, Politani Negeri \\ Samarinda, 75131 \\ zarta_poltanesa@yahoo.com
}

\begin{abstract}
Abstrak-His study aims to analyze the extent to which a mixture of wood waste and used newsprint can be used as raw material for making paper.This study used a completely randomized design with two replications. where the treatment given is a mixture composition between waste wood pulp and old newsprint pulp, each consisting of $0: 100 \%$ (A), 30\% $70 \%$ (B), 50\% : 50\% (C), 70\%: 30\% (D) and 100\%: $0 \%$ (E) of oven-dry weight of pulp per sheet of paperThe physical properties of paper pulp tested in the form of tear index, tensile index, crack index and folding resistance significantly affect the composition of the mixture of wood waste and used newsprint.The value of tear index, tensile index and folding resistance tend to decrease with the increase in the percentage of used newsprint to the composition of the mixture, while the value of the crack index increases. Wood waste and used newsprint can be used as raw materials in pulp and paper manufacture, especially in the treatment of mixed composition C (50\%:50\%.)
\end{abstract}

Key words-Paper Pulp, Wood Waste, Used Newspaper, Physical and Mechanical Properties of paper

\section{PENDAHULUAN}

Industri pulp dan kertas di Indonesia mempunyai prospek yang cukup cerah mengingat bahan bakunya masih sangat cukup tersedia dan permintaan akan pulp kertas terus meningkat dari tahun ke tahun. Indonesia menduduki peringkat ke sebelas sebagai produsen kertas dunia pada tahun 1999 dengan tingkat produksi 6,9 juta ton per tahun. Kapasitas terpasang industri pulp di Indonesia pada tahun 2000 mencapai 4,972 juta ton dan tahun 2016-2021 kapasitas terpasang industri kertas mencapai kenaikan 10 juta ton (APKI, 2020). dari Jumlah Industri pulp dan kertas nasional yang mencapai 84 perusahaan

Industri pulp dan kertas mengalami kesulitan dalam penyediaan bahan baku. Kesulitan bahan baku dapat terjadi akibat ketidaktaatan industri dalam menyeimbangkan penebangan dan penanaman kembali pohon, pemakaian kayu sebagai bahan baku pembuatan kertas juga harus dibatasi dalam rangka menjaga kelestarian alam.

Penggunaan kayu untuk bahan baku pulp dan kertas masih sangat dibutuhkan. Casey (1980) mengatakan bahwa pemakaian kayu untuk bahan baku pulp dan kertas masih relatif tersedia, mudah dalam hal penanganan dan penyimpanan dan menghasilkan kualitas pulp berkualitas tinggi. Di samping kayu, bahan berlignoselulosa yang dapat digunakan adalah limbah hasil pertanian (merang, jerami, dan ampas tebu), tandan kosong kelapa sawit, bambu, limbah kayu dan kertas dan atau karton bekas. Ketersediaan kayu yang masih sangat dibutuhkan industri pulp dan kertas semakin lama semakin terbatas sehingga alternatif pemenuhan bahan baku berlignoselulosa ini perlu memanfaatkan berbagai bahan lignoselulosa untuk kebutuhan bahan baku serat.

Pemanfaatan limbah penggergajian kayu sangat penting karena rendemen kilang penggergajian kayu berkisar antara 50-60 \% dan sisanya merupakan limbah kayu dalam bentuk serbuk, sabetan dan potongan kayu (Allia, 2019). Sedangkan Muladi (1996) mengatakan, besarnya persentase limbah yang terjadi yakni sebesar $36,78 \%$ dari operasi kegiatan pembalakan di tiga perusahaan pada kawasan hutan primer serta persentase limbah sebesar $35 \%$ adalah kegiatan industri penggergajian.

Rendemen kayu gergajian menurut Apkindo (1999) sebesar $50 \%$, maka diasumsikan bahwa limbah kayu gergajian yang dihasilkan pada periode tersebut, besarnya relatif sama dengan produksi yang dihasilkan. Data dari Departemen Perindustrian dan Perdagangan bahwa produksi kayu gergajian Indonesia tahun 1997 yaitu sebesar 11,485 juta $\mathrm{m}^{3}$ dan pada tahun 2001 produksinya menurun menjadi 4,326 juta $\mathrm{m}^{3}$. Hal ini berarti bahwa pasokan kayu bulat untuk bahan baku kayu gergajian semakin menipis.

Pemanfaatan limbah kayu, selain dapat memanfaatkan penggunaan kayu secara optimal juga 
dapat mengurangi limbah kayu khususnya limbah kayu Industri penggergajian dan memberi nilai tambah dengan penggunaan tersebut, karena limbah kayu industri penggergajian sebagian besar hanya digunakan untuk kayu bakar dan bahan baku untuk pembakaran batu bata.

Kertas bekas adalah semua jenis kertas dan karton yang tidak digunakan lagi untuk sumber serat yang diolah secara terpisah meliputi pembuatan pulp tanpa melalui proses pemasakan, kemudian dilanjutkan dengan penyaringan dan pembersihan (Achmadi et al, 1995).

Pertumbuhan produksi kertas koran pada tahun 1985 sebesar 62.600 ton, kemudian tahun 1992 produksi kertas koran mencapai 169.200 metrik ton. Pertumbuhan rata-rata per tahun sebesar 24,88 persen. Konsumsi kertas koran juga terjadi peningkatan, dimana pada tahun 1980 konsumsi kertas koran baru mencapai 99.800 ton, tahun 1992 konsumsinya sudah mencapai 135.285 metrik ton, dengan pertumbuhan rata-rata 5,74 persen. Produksi kertas koran tahun 2000 sudah mencapai 495.250 metrik ton dengan konsumsi pada tahun tersebut sekitar 175.985 metrik ton (IPPA, 2001). Melihat konsumsi dan produksi kertas koran yang cukup besar dan terus meningkat, maka limbah kertas koran yang dihasilkan juga meningkat seiring dengan permintaan kertas koran, dimana pemanfaatan kertas koran bekas selama ini sebagian besar hanya digunakan sebagai pembungkus.

Tingginya biaya pembuatan pulp dan semakin berkurangnya kemampuan alam untuk menyediakan sumber serat mendorong pencarian alternatif lain sebagai penggantinya. Upaya yang telah dilakukan untuk mencari sumber serat, salah satunya yaitu dengan memanfaatkan serat sekunder. Jenis serat ini dapat diperoleh dari daur ulang kertas dan atau karton bekas. Pemanfaatan kertas koran sebagai sumber serat diharapkan memberi dukungan dalam menyongsong penerapan sistem ekolabel yang mengharuskan produsen pulp memperhatikan produk-produk yang ramah lingkungan, baik dalam hal bahan baku, proses produksi, maupun setelah digunakan.

Kertas koran bekas berpotensi besar sebagai sumber serat sekunder, dapat di daur ulang menjadi pulp untuk dimanfaatkan sebagai bahan baku pembuatan kertas. Dikatakan Fengel dan Wegener (1995), limbah kertas atau karton sudah merupakan sumber serat yang tidak dapat ditinggalkan dan bahkan akan menjadi lebih penting dikemudian hari disebabkan oleh perbaikan teknik pembuatan pulp serat sekunder. Pemanfaatan koran bekas untuk bahan baku pulp kertas, selain dapat mengurangi limbah dan meningkatkan nilai tambah koran bekas, juga dapat mengurangi penggunaan kayu dari hutan.

Limbah kayu gergajian dan kertas koran bekas merupakan limbah yang sangat potensil untuk dapat dimanfaatkan sebagai bahan baku dalam pembuatan pulp dan kertas, Pemanfaatan limbah kayu dan kertas koran bekas, akan memberi nilai tambah yang sangat berarti dan dapat mengurangi penggunaan kayu dan mengurangi limbah kertas koran bila dioptimalkan penggunaannya. Karakteristik bahan baku yang digunakan ini yaitu limbah kayu dan koran bekas juga sangat berperan dalam kualitas pulp kertas yang dihasilkan, sehingga juga perlu dikaji atau dianalisis.

Hal yang paling penting sesuai tujuan akhir penelitian yang dinginkan adalah menganalisa kualitas kertas yang dihasilkan dari berbagai kombinasi campuran limbah kayu dan kertas koran bekas, sehingga akan diketahui sejauh mana campuran kedua bahan baku ini dapat digunakan, dan pada komposisi campuran berapa yang terbaik dihasilkan dalam pembuatan pulp kertas.

Penelitian ini bertujuan untuk menganalisis sampai sejauh mana campuran limbah kayu dan kertas koran bekas dapat dimanfaatkan sebagai bahan baku pembuatan kertas. Diharapkan hasil penelitian ini dapat memberi informasi kualitas pulp kertas dari campuran limbah kayu dan kertas koran bekas, sehingga dapat menghasilkan kombinasi campuran yang tepat untuk diolah sebagai bahan baku pembuatan pulp dan kertas.

\section{METODE PENELITIAN}

Bahan yang digunakan dalam penelitian ini adalah kertas koran bekas dan limbah kayu penggergajian yaitu limbah kayu Akasia (Acacia mangium Willd) dan Sengon (Paraserianthes falcataria L. Nielsen). Sedangkan bahan kimianya digunakan adalah $\mathrm{NaOH}$, minyak jarak, dan rosin soap.

Alat yang digunakan adalah Beater Hollander, Niagara Beater, Stone Refiner, hidropulper, alat pembuat lembaran, tearing tester, tensile tester, reflektometer, compression tester, Precision Cutter, Plate, dan Flute Tester

\section{Pelaksanaan Penelitian}

a. Persiapan Serpih Kayu dan Kertas Koran Bekas

Limbah kayu dari industri penggergajian berupa sebetan kayu Akasia dan Sengon, dibuat serpih dengan ukuran $2,5 \mathrm{~cm} \times 2,5 \mathrm{~cm}$ x $0,2 \mathrm{~cm}$. Serpih yang dibuat, ukurannya seseragam mungkin dan dikering udarakan sampai mencapai kadar air kesetimbangan.

Dalam penelitian ini digunakan contoh serpih kayu sebanyak 400 gram kering oven untuk setiap kali pemasakan, Jumlah ini merupakan hasil pencampuran dengan komposisi antara kayu akasia dan sengon yaitu masing-masing 50\%: 50\%.

Kertas koran bekas dipilih jenis koran yang akan direpulping yaitu beberapa koran lokal yang beredar di Bogor dengan gramatur $45-55 \mathrm{~g} / \mathrm{m}^{2}$ Untuk memudahkan proses repulping, maka dilakukan penyobekan kertas koran dengan ukuran seseragam mungkin setelah itu dilakukan perendaman 24 jam. 
b. Proses Pulping Limbah Kayu dan Repulping Kertas Koran

Proses pemasakan serpih dilakukan dengan cara proses soda panas terbuka. Perbandingan kayu akasia dan sengon yaitu $50 \%: 50 \%$ dari berat serpih kayu kering oven. Pencampuran dimaksudkan untuk menyeragamkan sifat-sifat yang berbeda yang dimiliki kedua kayu tersebut.

Pemasakan dilakukan pada suhu $100^{\circ} \mathrm{C}$ selama 2 (dua) jam, dimana penghitungan waktu dimulai pada saat pemasakan berada pada titik didih $100^{\circ} \mathrm{C}$. Konsentrasi bahan kimia yang digunakan adalah $\mathrm{NaOH}$ ; $8 \%$ dari berat serpih yang dimasak pada kondisi kering oven. Perbandingan antara serpih dengan larutan bahan kimia pemasak adalah $1: 8$ Serpih yang telah masak digiling pada beater hollander sampai 10$12^{0} \mathrm{SR}$ (787-837 ml CSF). Untuk meningkatkan derajat kehalusan pulp dilewatkan pada alat stone refiner hingga mencapai derajat kehalusan $14-16^{0} \mathrm{SR}$ (737-687 ml CSF) (Pasaribu, 1994). Kemudian dilewatkan di Niagara Beater hingga mencapai derajat kehalusan $\pm 300 \mathrm{ml} \mathrm{CSF}$.

Repulping kertas koran dilakukan dengan cara penguraian serat dengan menggunakan beater hollander tanpa tekanan. Derajat kehalusan pulp kertas koran yang digunakan sesuai dengan derajat giling pada saat dibentuk menjadi kertas yaitu berkisar \pm $300 \mathrm{ml} \mathrm{CSF}$ (Stoneman, 2017).

\section{c. Pencampuran Pulp Limbah Kayu dan Pulp Kertas Koran Bekas}

Pencampuran pulp limbah kayu dicampur dengan pulp dari kertas koran bekas dengan komposisi campuran masing-masing (70\%:30\%), (50\%:50\%), dan (30\%:70\%) berat pulp kering oven untuk setiap lembar kertas. Sebagai pembanding, dibuat lembaran kertas yaitu kontrol limbah kayu $100 \%$ dan kontrol kertas koran bekas $100 \%$.

\section{d. Pembuatan Lembaran Kertas}

Pembuatan lembaran dilakukan dengan menuangkan suspensi ke dalam alat pembentuk lembaran yang telah berisi air, setelah diaduk kran dibuka, alat dibuka kemudian diletakkan kertas penghisap dan digilas dengan dialasi setumpuk kertas dan plat logam, sehingga lembaran terbentuk pada kertas penghisap, selanjutnya lembaran dikempa pd penekan hidrolik dengan tekanan $4 \mathrm{~kg} / \mathrm{m}^{2}$. kemudian lembaran dikeringkan pd oven pada suhu $70-80^{\circ} \mathrm{C}$. Suhu dan kelembaban ruang sesuai SII 0388-81. lembaran kertas yang dibentuk memiliki gramatir 60 $\mathrm{g} / \mathrm{m}^{2}$.

\section{e. Pengujian Pulp dan Kertas}
(a) Pengukuran Gramatur (SNI 14-0439-1989)
(b) Ketahanan Tarik Kertas (SII 0436-81)
(c).Uji Ketahanan Lipat Kertas (SII 0527 - 81)
(d) Uji Ketahanan Retak Kartas (SII 0529-81)
(e ) Uji Ketahanan Sobek Kertas (SII 0435-81)

Penelitian ini menggunakan rancangan acak lengkap dengan dua ulangan. dimana perlakuan yang diberikan adalah komposisi campuran antara pulp limbah kayu dan pulp kertas koran bekas, masingmasing terdiri dari $0: 100 \%(\mathrm{~A}), \quad 30 \%: 70 \%(\mathrm{~B})$, $50 \%: 50 \%$ (C), $70 \%: 30 \%$ (D) dan $100 \%: 0 \%$ (E) dari berat kering oven pulp per lembar kertas.

\section{HASIL DAN PEMBAHASAN}

\section{Sifat Limbah Kayu dan Kertas Koran Bekas}

Bahan baku yang digunakan dalam pembuatan kertas adalah limbah kayu dari industri penggergajian yaitu jenis kayu Akasia (Acacia mangium Willd) dan Sengon (Paraserianthes falcataria L. Nielsen), sedangkan limbah kertas yang digunakan adalah kertas koran bekas. Limbah kayu yang berbentuk potonganpotongan dan sebetan-sebetan kayu diperoleh dari industri penggergajian kayu di Kecamatan Leuw Liang Desa Cibanteng Kabupaten Bogor.

Rata-rata kadar air limbah kayu akasia dan sengon pada kondisi tersebut masing-masing berkisar 49,72\% dan 43,46\%. Untuk menyeragamkan kadar air kayu tersebut maka dilakukan pengkondisian kadar air selama kurang lebih satu bulan. Pengkondisian tersebut dilakukan setelah kayu dibuat menjadi serpih kayu, dimana kadar air kayu akasia dan sengon setelah dikondisikan masing-masing 19,23\% dan 16,87 \%. Suchsland dan Woodson (1991) mengatakan bahwa pemantauan kadar air kayu sangat diperlukan untuk menentukan output yang diperoleh yang ditentukan berdasarkan berat kering oven serat.

Kertas koran bekas yang digunakan berasal dari kolektor atau pengumpul koran bekas sebanyak 3,0 kg dengan rincian, kertas koran Kompas sebesar 1,31 kg (43,8\%), Republika 0,926 kg (30,87 \%), Media Indonesia $0,468 \mathrm{~kg}(15,6 \%)$, dan Suara Pembaharuan $0,296 \mathrm{~kg}(9,73 \%)$. Hasil pengukuran kadar air kertas koran berkisar antara 10,69 - 12,78\% dengan rata-rata $11,18 \%$. Pengukuran kadar air dilakukan untuk menentukan jumlah koran yang dibutuhkan untuk penguraian serat dalam proses repulping,

\section{Kondisi Pulp Limbah Kayu dan Pulp Kertas Koran Bekas}

Dalam proses pulping limbah kayu industri penggergajian, dilakukan pencampuran antara kayu akasia dengan kayu sengon pada komposisi masingmasing 50 persen dari berat kering oven yang dimasak. Adapun nilai rata-rata rendemen pulp campuran limbah kayu (akasia + sengon), pulp kertas koran dan waktu giling yang digunakan dalam proses tersebut dapat dilihat pada Tabel 1 .

Tabel 1. Rata-rata Rendemen Pulp dan Waktu Giling Pulp Campuran Limbah Kayu dan pulp kertas koran bekas, serta Bilangan Kappa Limbah Kayu 


\begin{tabular}{|c|c|c|}
\hline Kondisi Pulp & $\begin{array}{c}\text { Pulp Limbah } \\
\text { Kayu }\end{array}$ & $\begin{array}{c}\text { Pulp Koran } \\
\text { Bekas }\end{array}$ \\
\hline Rendemen (\%) & 76,21 & 90.36 \\
Bilangan Kappa & 21,72 & - \\
Waktu giling (menit) & 63,94 & 25,72 \\
\hline
\end{tabular}

Tabel 1 menunjukkan bahwa rendemen pulp yang dihasilkan pada proses pemasakan lebih kecil dibanding pada pulp Koran bekas. Kecilnya rendemen pulp limbah kayu diduga karena terlarutnya komponen lignin dan poliosa dalam proses pemasakan dan defibrasi serat pada alat refining, dimana rendemen pulp pada proses ini masih berada pada kisaran yang sesuai proses semi kimia yaitu $65-85 \%$ (Fengel.dan Wegener, 1995). Sedangkan bilangan kappa tergolong kelas kualita II (besaran 18-22) dengan nilai 21,72.

Waktu giling pulp limbah kayu pada derajat giling $10-12^{0} \mathrm{SR}$ (787-837 ml CSF) adalah 63,34 menit. Hal ini terjadi karena lignin merupakan komponen yang memperkuat dinding sel telah mengalami pelunakan. Pelunakan lignin dapat mempercepat defibrasi serat dalam pemasakan serpih pada suhu $100^{\circ} \mathrm{C}$ selama dua jam. Kondisi tersebut $\mathrm{pH}$ bersifat basa atau di atas 7 , dimana serat lebih mudah basah dan mengembang sehingga dapat mempercepat atau memperbaiki waktu penggilingan (Ngatijo et al, 1997).

Repulping kertas koran bekas yang dilakukan, menghasilkan rendemen pulp yang berkisar antara 87,55 - 91,79 \% dengan rata-rata 90,36\% pada kondisi derajat giling 347- 389 CSF dengan waktu defibrasi serat antara 22,15 - 27,68 menit, dengan rata-rata waktu defibrasi 25,72 menit (Tabel 2). Waktu defibrasi pada kertas koran relatif singkat karena ikatannya tidak diikat lignin dan sudah berbentuk serat (Anonim, 1976).

Bilangan kappa yang dihasilkan pulp limbah kayu adalah 21.72 (Tabel 2), hal ini menunjukkan bahwa sisa lignin pada pulp cukup rendah, rendahnya lignin menunjukkan pulp yang dihasilkan sudah matang. Menurut Casey (1980), lignin akan menurunkan kekuatan jalinan antar serat dalam pembentukan lembaran pulp, karena bersifat hidrofobik serta menghambat proses fibrilisasi serat pada saat penggilingan. Banyaknya serat pulp kertas koran dan serat pulp limbah kayu dalam proses pemasakan, yang dapat tertampung pada berbagai ukuran Ukuran Saringan dapat dilihat pada tabel 2.

Tabel 2. Ukuran saringan fraksi pulp limbah kayu dan koran bekas

\begin{tabular}{|l|c|c|c|c|c|}
\hline \multirow{2}{*}{ Serat Pulp } & \multicolumn{5}{|c|}{ Ukuran Saringan (mesh) } \\
\cline { 2 - 6 } & 20 & 45 & 60 & 100 & $\begin{array}{c}\text { Lolos } \\
100\end{array}$ \\
\hline $\begin{array}{l}\text { a. Pulp } \\
\begin{array}{l}\text { Limbah kayu } \\
\text { (\%) }\end{array}\end{array}$ & 0 & 24,23 & 48,40 & 16,94 & 10,43 \\
$\begin{array}{l}\text { b. Pulp Koran } \\
\text { bekas (\%) }\end{array}$ & 0 & 7,85 & 16,12 & 31,84 & 44,19 \\
\hline
\end{tabular}

Tabel 2 terlihat bahwa baik fraksi pulp limbah kayu maupun fraksi pulp kertas koran semuanya lolos saringan 20 mesh. Jumlah fraksi serat pulp limbah yang tertampung pada saringan 60 mesh adalah yang tertinggi dan terendah pada saringan 100 mesh, sedangkan yang lolos saringan 100 mesh lebih kecil dari saringan yang digunakan. Fraksi serat pulp limbah kayu yang tertampung pada setiap saringan relatif berbeda walaupun proses refining pulp kayu di stone refiner relatif seragam karena serat halus yang terdegradasi setelah proses penggilingan lebih besar.

Serat pulp kertas koran yang tertampung pada saringan, tertinggi pada saringan 100 mesh dan terendah pada saringan 45 mesh, adapun serat pulp kertas koran yang lolos saringan 100 mesh lebih besar dari serat yang tertampung pada berbagai saringan yang digunakan. Klasifikasi Clark yang dikutip Casey (1960) menunjukkan bahwa serat pulp yang tertampung pada saringan antara 48-100 mesh adalah termasuk golongan serat dengan panjang serat antara $0,95-1,70 \mathrm{~mm}$. Serat yang lolos saringan 100 mesh termasuk golongan serat sangat pendek yang berukuran panjang $0,1 \mathrm{~mm}$. Hal ini memberi petunjuk bahwa serat sekunder (serat kertas koran) termasuk serat pendek dan lebih pendek dibanding dengan serat pulp limbah kayu (Haygreen dan Bowyer, 1996. ).

Jika dibandingkan antara fraksi serat pulp limbah kayu dan pulp kertas koran dengan berdasarkan klasifikasi Clark, maka pulp kertas koran mempunyai persentase serat pendek lebih banyak dibanding serat panjang dan juga kondisi seratnya lebih banyak yang patah atau tidak utuh yang berbentuk serat-serat halus. Hal ini dimungkinkan karena pulp kertas koran merupakan serat sekunder yang telah mengalami proses daur ulang yang berulang dengan cara repulping (Hay, dkk., 2018).

\section{Sifat Fisis Lembaran Kertas}

Nilai hasil uji sifat fisik pulp atau kertas berupa indeks sobek, indeks tarik, indeks retak, dan ketahanan lipat dapat dilihat pada Lampiran 1.

a. Indeks Sobek

Nilai indeks sobek yang diperoleh dari hasil pengujian berada antara $3.72-11.423 \mathrm{Nm}^{2} / \mathrm{g}$. Nilai yang dimaksud diatas termasuk dalam perlakuan control yaitu tanpa campuran limbah kayu dan tanpa kertas Koran bekas. Nilai tertinggi indeks sobek berada pada komposisi campuran $\mathrm{B}(70 \%: 30 \%)$ dengan nilai $10.875 \mathrm{Nm}^{2} / \mathrm{g}$ dan terendah pada komposisi campuran $\mathrm{D}(30 \%: 70 \%)$ dengan nilai $5.105 \mathrm{Nm}^{2} / \mathrm{g}$. Nilai Indeks sobek yang diperoleh masih lebih kecil yang diamati Allia (2019) pada pisang abaka dengan nilai indeks sobek $15.69 \mathrm{Nm}^{2} / \mathrm{g}$ (March dan Springer, 2019)

Hasil pengujian sifat kekuatan kertas menyangkut indeks sobek kertas menunjukkan bahwa kertas yang komposisi campuran limbah kayu lebih banyak, akan mempunyai sifat kekuatan lebih baik, dimana terlihat bahwa nilai indeks sobek kertas akan menurun dengan 
bertambahnya campuran kertas koran bekas pada setiap lembaran kertas.

Hasil analisis sidik ragam menunjukkan bahwa indeks sobek sangat berpengaruh terhadap respon perbedaan komposisi campuran limbah kayu dan kertas Koran bekas Hal ini disebabkan adanya perbedaan persentase serat yang kondisinya lebih baik khususnya pada persentase limbah kayu yang lebih besar.

Faktor utama yang juga menentukan indeks sobek adalah fleksibilitas dan panjang serat. Penurunan fleksibilitas serat menyebabkan berkurangnya daya ikat sehingga waktu mengalami penyobekan banyak serat yang terpisah dengan mudah dalam keadaan utuh. Gaya sobek yang diperlukan menjadi kecil, serat juga menjadi mudah putus karena kekuatan intrinsiknya berkurang akibat penambahan kertas koran bekas. Selain itu pada saat repulping kertas Koran bekas banyak serat yang terpotong sehingga akan mengurangi ketahanan sobek dengan bertambahnya kertas Koran bekas pada komposisi campuran yang dibuat. .

\section{b. Indeks Tarik}

Hasil uji indeks tarik kertas, nilainya berada antara 22.67 sampai $51.73 \mathrm{Nm} / \mathrm{g}$. Nilai tersebut termasuk nilai perlakuan kontrol yaitu tanpa campuran limbah kayu dan tanpa kertas Koran bekas. Nilai tertinggi indeks tarik yaitu pada komposisi campuran B(70\%:30\%) dengan nilai $41,4 \mathrm{Nm} / \mathrm{g}$, sedangkan nilai indeks tarik terendah pada komposisi campuran $\mathrm{D}(30 \%$ : 70\%). Jika dibandingkan perlakuan kontrol, yaitu tanpa campuran limbah kayu dan tanpa campuran kertas Koran bekas, maka komposisi campuran B(70\%:30\%) nilai indeks tariknya jauh lebih baik dibanding control kertas Koran bekas (Kleinau, 1987).

Nilai indeks tarik di atas lebih kecil dari nilai indeks tarik Abaka 115,72 Nm/g (Allia, 2019). Sedangkan Ibnusantosa (1987) mendapatkan nilai indeks tarik Jerami $22.88-42.66 \mathrm{Nm} / \mathrm{g}$ dan Indeks tarik Bagas $36,79 \mathrm{Nm} / \mathrm{g}$.

Nilai indeks tarik kertas cenderung menurun dengan adanya penambahan kertas koran bekas pada setiap lembaran kertas. Indeks tarik kertas berpengaruh sangat nyata terhadap perlakuan komposisi campuran limbah kayu dan kertas koran bekas. Kondisi yang dapat menentukan indeks tarik lebih baik adalah plastisitas dan fleksibilitas serat, proses penggilingan serat juga dapat meningkatkan kedua sifat ini. Kondisi ini memungkinkan, bahwa nilai fleksibilitas serat pulp limbah kayu lebih baik dibanding pulp kertas Koran bekas, hal ini merupakan salah satu indikator yang dapat menentukan indeks tarik kertas lebih besar pada konposisi campuran yang limbah kayunya lebih banyak.

\section{c. Indeks Retak}

Nilai indeks retak yang diperoleh berada antara 0,93 sampai $3,34 \mathrm{kPam}^{2} / \mathrm{g}$. Nilai tersebut termasuk nilai perlakuan control yaitu tanpa campuran limbah kayu dan tanpa kertas Koran bekas.

Nilai tertinggi indeks retak berada pada komposisi campuran $\mathrm{C}(50 \%: 50 \%)$ dengan nilai $2,59 \mathrm{kPam}^{2} / \mathrm{g}$. dan terendah pada komposisi campuran $\mathrm{B}(70 \%: 30 \%)$ dengan nilai $1,79 \mathrm{kPam}^{2} / \mathrm{g}$.. Nilai Indeks retak yang diperoleh masih lebih kecil yang diperoleh Allia (2019) pada pisang Abaka dengan nilai indeks retak 8,43 $\mathrm{kPam}^{2} / \mathrm{g}$. Hal yang sedikit berbeda didapatkan Ibnusantosa (1987) bahwa nilai indeks retak Jerami $2,69-4,41 \mathrm{kPam}^{2} / \mathrm{g}$, sedangkan nilai yang lebih rendah diperoleh Allia (2019) bahwa nilai indeks retak Acacia mangium yaitu berkisar antara 0,44-1,63 $\mathrm{kPam}^{2} / \mathrm{g}$.

Indeks retak cenderung meningkat dengan adanya penambahan pulp kertas Koran bekas pada komposisi campuran lembaran kertas yang dibuat. Keberadaan kandungan lignin dalam lembaran kertas sangat menentukan nilai indeks retak, semakin tinggi kandungan lignin, maka kekuatan retak semakin kecil. Kandungan lignin pada limbah kayu lebih besar dibanding pada pulp kertas koran bekas. hal ini diduga menyebabkan nilai indeks retak kecil, yang komposisi limbah kayunya lebih banyak. Hasil analisis sidik ragam, menunjukkan bahwa indeks retak kertas berpengaruh sangat nyata terhadap komposisi campuran limbah kayu dan kertas Koran bekas.

Casey (1980) mengatakan, indeks retak dipengaruhi oleh proses penggilingan, dimana pada proses penggilingan terjadi proses fibrilisasi atau pemisahan serat yang dapat memperluas kontak antar serat, sehingga menambah areal ikatan serat satu dengan lainnya melalui ikatan hidrogen, yang menyebabkan lembaran pulp kertas mempunyai kekuatan tinggi. Hal lain dikatakan, adanya pelarutan lignin menyebabkan terjadinya penipisan dinding sel sehingga nilai indeks retak meningkat dan terbentuknya lembaran dengan ikatan yang lebih baik. Juga dikatakan, panjang serat merupakan faktor yang berpengaruh terhadap nilai indeks retak, sedangkan ikatan antar serat merupakan faktor paling menentukan terhadap kekuatan retak.

Indeks retak kertas tergolong kelas kualita III besaran nilai 150-200 kPa (Miisra, 1977 dalam Pasaribu 1989) yang terdapat pada komposisi campuran $\mathrm{C}(50 \%: 50 \%)$ dengan nilai $2,595 \mathrm{kPam}^{2} / \mathrm{g}$ dan setelah dikonversi mencapai $155,7 \mathrm{kPa}$. Kecilnya nilai indeks retak ini dipengaruhi oleh besar kecilnya kandungan lignin pada komposisi campuran limbah kayu dan kertas Koran bekas, Dimana semakin tinggi kandungan lignin maka nilai indeks retak semakin besar. Nilai kandungan lignin pulp limbah kayu 15,08 $\%$ dan pulp koran bekas $4,89 \%$. .

Selain iitu nilai indeks retak dipengaruhi oleh lamanya penggilingan dalam penguraian serat, penggilingan serat yang sesuai akan menyebabkan ikatan serat akan lebih baik dan meningkatkan kekuatan pulp (Casey, 1980).

\section{d. Ketahanan Lipat}

Nilai ketahanan lipat yang diperoleh dari hasil pengujian berada antara 1.76 sampai 2.11 kali 
(Emerton, 1980). Nilai yang dimaksud di atas termasuk dalam perlakuan control yaitu tanpa campuran limbah kayu dan tanpa kertas Koran bekas. Nilai ketahanan lipat tertinggi berada pada komposisi campuran $\mathrm{B}(70 \%: 30 \%)$ dengan nilai 2.07 kali dan terendah pada komposisi campuran $\mathrm{D}(30 \%: 70 \%)$ dengan nilai 1.87 kali.

Ketahanan lipat kertas cenderung menurun dengan adanya penambahan kertas koran bekas pada komposisi campuran limbah kayu dan kertas koran bekas. Kondisi serat berupa panjang serat dan dinding selnya berhubungan erat dengan sifat ketahanan lipat kertas. Panjang serat pulp limbah kayu lebih panjang dibanding pulp kertas koran bekas, hal yang sama juga terjadi pada dinding sel dan diameter selnya. Kondisi seperti ini diduga akan meningkatkan ketahanan lipat kertas.

Hidayat T. (1991) mengatakan bahwa formasi lembaran kertas yang lebih baik, akan semakin sedikit titik lemah pada lembaran kertas, sehingga jalinan serat tidak mudah rusak karena pelipatan dan tarikan kertas. Sedangkan Casey (1980) mengatakan, ketahanan lipat dipengaruhi oleh kekuatan ikatan antar serat. Serat dengan dinding sel tipis dan berdiameter besar lebih mudah dipipihkan untuk membentuk permukaan yang luas sehingga ikatan antar serat menjadi lebih baik dan akan memberikan ketahanan lipat yang juga lebih baik.

Hasil analisis sidik ragam menunjukkan bahwa ketahanan lipat kertas berbeda sangat nyata terhadap komposisi campuran limbah kayu dan kertas koran bekas. Kondisi ini diduga adanya perbedaan formasi serat antara limbah kayu dan kertas koran bekas, formasi serat yang rapat dengan ikatan yang kuat akan meningkatkan ketahanan lipat. Hal yang juga menentukan yaitu fleksibilitas serat yang berkurang dengan bertambahnya penambahan kertas koran bekas pada komposisi campuran lembaran kertas, sehingga dapat menurunkan ketahanan lipat.

Ketahanan lipat tertinggi pada komposisi campuran $\mathrm{C}(50 \%: 50 \%)$ dengan nilai 1,99 kali, yang tergolong dalam kelas kualita III 1,0 - 2,0 (Miisra, 1977 dalam Pasaribu 1989). Ketahanan lipat juga berkaitan dengan kandungan lignin pada lembaran kertas, semakin rendah kandungan ligninnya maka nilai ketahanan lipat yang dihasilkan semakin tinggi.

Degradasi selulosa pada limbah kayu dan koran bekas dalam proses pulping dan repulping juga dapat menurunkan nilai ketahanan lipat. Kandungan selulosa pulp limbah kayu 72,27 \% sedangkan pulp kertas koran bekas sebesar 39,59\%, hal ini memungkinkan terjadinya penurunan nilai ketahanan lipat dengan berkurangnya persentase limbah kayu ke dalam komposisi campuran.

\section{KESIMPULAN}

Sifat fisis yang diujikan berupa Indeks sobek, indeks tarik, indeks retak dan ketahanan lipat berpengaruh nyata terhadap perlakuan komposisi campuran limbah kayu dan kertas koran bekas.

Nilai indeks sobek, indeks tarik dan ketahanan lipat cenderung menurun dengan bertambahnya persentase kertas koran bekas terhadap komposisi campuran, sedangkan nilai indeks retak meningkat.

Limbah kayu dan kertas koran bekas dapat digunakan sebagai bahan baku dalam pembutan pulp dan kertas, terutama pada perlakuan komposisi campuran $\mathrm{C}(50 \%: 50 \%$.).

\section{DAFTAR PUSTAKA}

Achmadi, S., A.H. Pudjaatmaka, T. Hadisoemarto dan Haryanto. 1995. Kamus Kimia Terapan : Pulp dan Kertas. Pusat Pembinaan dan Pengembangan Bahasa Departemen Pendidikan dan Kebudayaan Jakarta. Jakarta.

Allia. 2019. Sifat Pulp Abaka Asal Indonesia. Skripsi. Jurusan Teknologi Hasil Hutan. Fakultas Kehutanan. Institut Pertanian Bogor. Bogor

Anonim . 1976. Vadenecum Kehutanan Indonesia. Direktorat Jenderal Kehutanan Departemen Pertanian. Jakarta.

APKI. 2020. Berita Industri Pulp dan Kertas Indonesia. Bulletin Assosiai Industri Pulp dan Kertas Indonesia. Jakarta.

Apkindo. 1999. Konsolidasi Industri Kayu Lapis Untuk Memantapkan Pranannya pada Pembangunan Berkelanjutan. Makalah Lokakarya Kayu Lapis. Jakarta.

Basic Format for Books

Emerton. 1980. The Fibrous Raw Materials of Paper. Hand Book of Paper Science. The Raw Materials of Processing of Paper Making. Volume I. Amsterdam

Fengel, D. dan G. Wegener. 1995. Kayu : Kimia, Ultrastruktur, Reaksi-reaksi. Gadjah Mada University Press. Balaksumur, Yogyakarta, Indonesia. (Terjemahan).

Hay, P. P. J., Bacaltchuk, J., Stefano, S., \& Kashyap, P. (2018). Psychological treatments for bulimia nervosa and binging. Cochrane Database of Systematic Reviews. https://doi.org/10.1002/14651858.CD000562.pub3

Haygreen, J.G. dan J.L. Bowyer 1996. Hasil Hutan dan Ilmu Kayu. Suatu Pengantar. UGM Press. Bulaksumur. Jogyakarta. (Terjemahan).

Hidayat T. dan S. Tjiptosoedirdjo. 1992. Penggunaan Pulp Albizia falcataria pada Pembuatan Kertas Koran. Berita Selulosa. Volume XXVIII (1) pp. 38

IPPA. 2001. Directory 2001. Indonesian Pulp and Paper Industry. Indonesian Pulp and Paper Association. PT. Gramedia-Jakarta

Journal article from the Cochrane Database of Systematic Reviews

Journal article with an article number

Kleinau, J.H. 1987. Secondary Fibers Recycling. (ed) M.J. Kocurek (ed). Pulp and Paper 
Manufacture. Volume 3. Secondary Fiber and Non Wood Pulping. Joint Textbook Comittee of The Paper Industry.

Last Name, A. A. (Year of publication). Title of work: Capital letter also for subtitle. Publisher Name.

March, E., \& Springer, J. (2019). Belief in conspiracy theories: The predictive role of schizotypy, Machiavellianism, and primary psychopathy. PLoS One, 14(12): Article e0225964. https://doi.org/10.1371/journal.pone.0225964

Muladi S. 1996. Quantification and Use of Dipterocarp Wood Residue in East Kalimantan. Dipterocarp Forest Ecosystems. Towards Sustainable Management. Wood Scientific Publishing Co, Pte. LTd Singapore. pp. 603-615

Pasaribu, R.A. 1989. Kualita Pulp dan Kertas Beberapa Jenis Kayu Hutan Tanaman Industri, Proceedings Diskusi Sifat dan Kegunaan Jenis HTI. Badan Litbang Kehutanan. Departemen Kehutanan. Jakarta.

Pulp and Paper. 1980. Chemistry and Chemical Technology. Third Edition Volume II. Interscience Publisher Inc., New York.

research: Implications for college students. Journal of Postsecondary Education and Disability, 31(1): 2458. https://www.ahead.org/professionalresources/publications/jped/archived-jped/jpedvolume-31

Stoneman, R. (2017). Alexander the Great: A life in legend. Yale University Press.

Suchsland, O. dan G.E. Woodson. 1991. Fiberboard Manufacturing Practices In The United States. United States Department of Agricultural. 